\title{
Treatment Options for Marine Wastewater Discharges
}

Philip J. W. Roberts

DOI 10.4322/dae.2016.009

\section{ABSTRACT}

Some aspects, especially environmental impacts and costs, of wastewater disposal through marine outfalls are discussed. It is argued that the scheme should be thought of as a system, comprising the treatment plant, the outfall and diffuser, and the near field where rapid dilution is achieved. Environmental impacts should be regulated by a mixing zone approach that accounts for the very rapid initial mixing. "End-of-pipe" limitations or specification of arbitrary treatment levels should be discouraged. Water quality requirements, including those for toxics and bacteria, can be met by an effective outfall, i.e. one that discharges far from shore with high dilution, and preliminary treatment such as milliscreening. Secondary or other advanced treatment is rarely necessary. This is illustrated by the Cartagena, Colombia, outfall. The cost of disposal by an effective outfall and preliminary treatment is of the order of one tenth that of secondary treatment when amortized over 25 years.

Keywords:Outfalls; Marine; Wastewater treatment; Environmental impacts

\section{RESUMO}

São discutidos alguns aspectos, especialmente os impactos e custos ambientais, de saneamento de águas residuais através de emissários submarinos. Argumenta-se que o esquema deve ser pensado como um sistema, compreendendo a estação de tratamento, o emissário e difusor, e o campo próximo onde a rápida diluição é alcançada. Os impactos ambientais devem ser regulados por uma abordagem de zona de mistura que leva em conta uma mistura inicial muito rápida. Limitações "end-of-pipe" ou especificação de níveis de tratamento arbitrários devem ser desencorajados. Requisitos de qualidade da água, incluindo os de produtos tóxicos e bactérias, podem ser atendidos por um emissário eficaz, ou seja, aquele que descarrega longe da costa, com alta diluição e tratamento preliminar, como milipeneiras. Tratamento secundário ou outro tratamento avançado raramente é necessário. Isto é ilustrado pelo emissário de Cartagena, Colômbia. O custo da disposição por um emissário eficaz e tratamento preliminar é da ordem de um décimo do tratamento secundário quando amortizado em 25 anos.

Palavras-chave: Emissários; Marinho; Tratamento de água poluída; Impactos ambientais

\section{INTRODUCTION}

Appropriate treatment levels for marine wastewater discharges have long been contentious and the source of vigorous debate. In this paper we discuss some of the issues involved in wastewater disposal through outfalls into a coastal environment.

A typical disposal scheme, Figure 1, consists of a treatment plant and an outfall. The outfall is a pipeline or tunnel, or combination of the two, which terminates in a diffuser. Outfalls typically range from 1 to $4 \mathrm{~km}$ long and discharge into waters 20 to $70 \mathrm{~m}$ deep, although they may be longer or shorter if the seabed slope is unusually flat or steep.

The disposal scheme should be thought of as a system, comprising the treatment plant, outfall, diffuser, and also the region round the diffuser (known as 
the near field) where rapid mixing and dilution occurs. This is illustrated schematically in Figure 1.

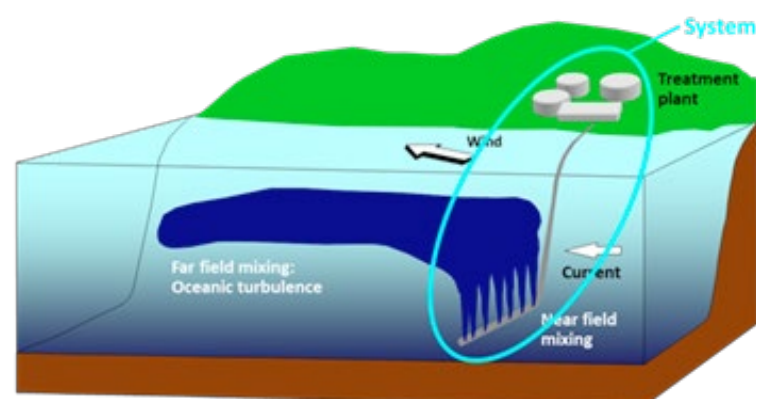

Figure 1: A marine wastewater disposal scheme: Treatment plant, outfall pipe, and diffuser.

The objectives of the system are to dispose of wastewater in a safe, economical, and reliable way with minimal impacts to the receiving water. This means that the local ecosystem and the health of the public that are swimming and using nearby beaches are protected, and that the outfall functions reliably with minimal maintenance. These objectives can be usually achieved by an effective outfall that has sufficient depth to ensure high initial dilution and sufficient length to prevent contamination of beaches.

\section{ENVIRONMENTAL AND WATER QUALITY ASPECTS}

Environmental and human health impacts of marine discharges are controlled by water quality standards set by some regulatory authority. They should ensure that:

- Concentrations of bacteria are reduced to safe levels to protect human health;

- Concentrations of toxics and other contaminants are reduced to safe levels to protect the local ecosystem;

- Ecosystem products of the effluent (organic carbon, nutrients, etc.) are kept within allowable limits to prevent eutrophication;

- Dissolved oxygen concentrations and biochemical oxygen demand (BOD) are kept within allowable limits;
- Local particulate deposition is not excessive;

- The wastefield is not visible on the water surface.

According to the National Research Council (NRC, 1993), a wastewater constituent may be considered to be of high concern if it:

“...poses a significant risk to human health and ecosystems (e.g. if it contaminates fish, shellfish and wildlife, causes eutrophication, or otherwise damages marine plant and animal communities) well beyond points of discharge and is not under demonstrable control. A wastewater constituent may be generally considered to be of lower concern if it causes only local impact or is under demonstrable control."

Using these criteria, the NRC developed a list of anticipated priorities for wastewater constituents in coastal urban areas as shown in Table 1.

Table 1: Pollutants of major concern for Coastal Discharge (NRC, 1993)

\begin{tabular}{|c|c|c|}
\hline Priority & Pollutant groups & Examples \\
\hline \multirow{3}{*}{ High } & Bacteria and Pathogens & Enteric viruses \\
\hline & Toxic organic chemicals & $\mathrm{PAHs}$ \\
\hline & Nutrients & Nitrogen \\
\hline \multirow{3}{*}{ Intermediate } & Selected trace metals & Lead \\
\hline & Others hazardous materials & Oil, chlorine \\
\hline & Plastics and floatables & $\begin{array}{c}\text { Beach trash, oil, and } \\
\text { grease }\end{array}$ \\
\hline \multirow{2}{*}{ Low } & Biochemical oxygen demand & \\
\hline & Solids & \\
\hline
\end{tabular}

The high priority pollutants can be readily controlled by an effective outfall combined with appropriate wastewater treatment. Although nutrients are listed as high priority, they are actually not usually a concern for discharges to open coastal waters with good flushing.

They are more of a problem in enclosed water bodies with poor flushing such as lakes, bays, or estuaries, where eutrophication may occur. Pathogens are microorganisms that can cause disease in humans. They are assumed to be controlled if the level of an indicator organism (an organism that 
indicates the presence of sewage) is below some specified standard or guideline. They can be controlled by a combination of initial dilution, oceanic diffusion, and mortality, as discussed in Roberts et al. (2010). Toxic organic chemicals and trace metals can cause adverse effects in aquatic organisms and humans. They can be addressed by, for example, applying the limitations prescribed in the California Ocean Plan, as discussed below. This can usually be accomplished by initial dilution alone for regular domestic sewage, but source control may be needed for industrial discharges.

Intermediate level constituents can also be controlled by treatment and dilution. Plastics and other particulate floatables should be removed by treatment such as screening. Other floatables, especially grease and oil, are of more concern since they may contain pathogens and may be blown onshore by winds (see Figure 1). As discussed below, milliscreening, especially when combined with other forms of treatment such as flotation, can remove substantial quantities of grease and oil and other floatables.

It may seem surprising that biochemical oxygen demand (BOD) is low priority in Table 1. This is because high initial dilution and the large surface area available for re-aeration generally results in negligible depletion of dissolved oxygen. Solids are also ranked low priority due to the ability to control them with treatment and high dilution. The potential for accumulation on the seabed, and their possible association with toxic organic chemicals, metals, and pathogens should be addressed, however.

Mathematical modeling and monitoring of operating outfalls show that their effects are generally limited to a small area, typically a few hundred meters around the discharges. This is true even for substantial discharges of essentially raw sewage, for example the Ipanema outfall in Rio de Janeiro.

The key parameters in the design of municipal wastewater systems are generally bacteria, float- ables, and grease and oil. Toxics are readily controlled by dilution. Bacteria are best controlled by locating the outfall so that transport of wastewater to beaches or other water contact areas is virtually eliminated. The outfall should be designed, however, that, in the unlikely event that transport to beaches does occur, the combination of initial dilution, oceanic diffusion, and bacterial mortality reduces the bacteria to very low levels. Chlorination of the effluent is then unnecessary. As discussed above, other parameters such as nutrients, BOD, and dissolved oxygen will not usually be a concern unless the sewage is discharged to a shallow, poorly flushed coastline, or embayment.

\section{REGULATORY ASPECTS}

Because of the unique behavior of wastewaters discharged from an outfall into a coastal environment, defining and specifying regulations and how to apply them is quite difficult. Probably the first major attempt to do so was the California Ocean Plan (The Plan). It was first published in 1972 and has been updated several times since, most recently in 2015 (SWRCB, 2015). The Plan specifies beneficial uses of the ocean and requirements for water quality and discharges to protect them. The Plan, or parts of it, has been adopted by many environmental agencies around the world.

High near field dilution is often a specific design requirement. It can be readily achieved by a multiport diffuser that discharges the effluent as high velocity turbulent jets that rise through the water column. They entrain substantial quantities of seawater that can dilute the effluent to at least 100:1 within a few minutes after discharge and within a few hundred meters from the diffuser (Figure 1).

This high dilution and the rapid and very substantial contaminant reduction that it provokes are recognized by regulatory authorities through the concept of a mixing zone. Understanding mixing zones is the key to understanding the environmental impacts of an ocean outfall and how they are regulated. 
The mixing zone is a region of limited water use. For example, the US EPA regulations for toxics defines a mixing zone as:

"An area where an effluent discharge undergoes initial dilution and is extended to cover the secondary mixing in the ambient water body. A mixing zone is an allocated impact zone where water quality criteria can be exceeded as long as acutely toxic conditions are prevented."

Mixing zone water quality standards are usually limited to parameters for acute toxicity protection. Toxics can be readily controlled by, for example, satisfying the requirements of Table 1 (formerly Table B) of The Plan. For regular domestic sewage, this will usually be accomplished if an initial dilution of order 100:1 is maintained, although source control may be needed for industrial discharges.

It is important to note that these limits are specified at the mixing zone boundary rather than at the "end-of-pipe". For example, The Plan does not generally specify effluent limitations or treatment levels, instead it specifies effluent limits that will achieve water quality objectives after near field dilution. To emphasize this, it states that:

"Waste effluents shall be discharged in a manner which provides sufficient initial dilution to minimize the concentrations of substances not removed in the treatment."

Prevention of microbial contamination in order to protect human health is an essential part of outfall design; indeed, the main reason for an outfall project is often to solve a microbial contamination problem.

Bacterial standards are not normally imposed within or at the boundary of mixing zones unless the diffuser is located near areas of shellfish harvesting or recreational use. In that case, advanced treatment and chlorination of the effluent will probably be required. Instead, they are specified at water contact areas, such as the shoreline.
Meeting these bacterial standards is a major driver of outfall design. Various standards have been set by International and other agencies for protection of human health. For example, The World Health Organization (WHO, 2003) presented Guidelines for Safe Recreational Water Environments using intestinal enterococcus as the indicator organism. Because of the wide variations that always occur in bacterial sampling, the standards are generally expressed in statistical terms such as geometrical means or exceedance frequencies rather than instantaneous values.

Bacteria are best controlled by locating the outfall so that transport of wastewater to beaches or other water contact areas is virtually eliminated. The outfall should be designed, however, that, in the unlikely event that transport to beaches does occur, the combination of initial dilution, oceanic diffusion, and bacterial mortality reduces the bacteria to very low levels.

All water quality, health, and environmental objectives can be readily achieved by a suitable combination of outfall and diffuser location, effective dispersion and dilution of the effluent, and treatment. To achieve them, it is necessary for the designer to understand how wastewaters mix in coastal waters, to design the outfall and diffuser to promote efficient mixing, and to match the treatment level accordingly.

\section{APPROPRIATE TREATMENT FOR OCEAN OUTFALL DISCHARGES}

Wastewater treatment for ocean discharges is a contentious issue and is often arbitrarily specified. According to the WHO, the level of treatment has little bearing on the human health risk of discharge from an effective outfall. The risk from any effluent discharged through an effective outfall is low, even if only treated to preliminary or primary levels. Conversely, if a short (ineffective) outfall is used, even secondary treatment will not reduce the health risk to acceptable levels. Effluents dis- 
charged directly on the beach or from a short outfall constitute a high health risk; unfortunately, this commonly occurs in developing countries.

Preliminary treatment alone will usually suffice with an effective outfall. For domestic sewage this consists of milliscreens with apertures around one $\mathrm{mm}$.

To understand why advanced treatment is usually unnecessary, consider an outfall with a diffuser that effects an initial dilution of 100:1 (which can usually be easily accomplished). This corresponds to a $99 \%$ reduction in contaminant concentrations in the receiving water, which is far beyond the capabilities of even advanced conventional treatment processes. Diffuser mixing is therefore usually much more important than treatment in mitigating environmental impacts. This is why the diffuser and near field are included in the "system" in Figure 1.

\section{RELATIVE TREATMENT COSTS}

For coastal cities, especially in developing countries, the strategy of wastewater disposal through an effective outfall with preliminary treatment is an affordable, effective, and reliable solution that is simple to operate and with minimal health and environmental impacts. Mandating more advanced levels of treatment that are unaffordable often results in "no action," with continued contamination of water bodies and their associated health risks.

The lifetime cost of a typical urban wastewater scheme with advanced, for example secondary, treatment is much higher than one with primary treatment and an effective long ocean outfall. If the treatment is limited to removal of floatables and grease and oil, the economic comparison is even more favorable for the outfall. Also, increasing use of High Density Polyethylene (HDPE) makes outfalls even more attractive, especially for small to intermediate communities.

The reason for the large discrepancy in costs can be seen in the summary of relative costs for typical treatment processes and their removal efficiencies in Table 2, in which the processes are presented in increasing order of sophistication. This table includes some other processes, such as milliscreening and CEPT. Some of the treatment processes are unit processes that would be combined with others to constitute a treatment plant. For example, primary treatment may include screening, grit chambers, and sedimentation tanks. Onsite treatment systems commonly use subsurface disposal, especially septic tanks. It can be used as a high-density treatment system if the soil is permeable enough and there is no significant risk of groundwater contamination.

Table 2: Typical Treatment Plant Removal Capabilities and Costs (NRC, 1993)

\begin{tabular}{|c|c|c|c|c|c|c|c|}
\hline \multirow{3}{*}{ Constituent } & \multicolumn{7}{|c|}{ Treatment process } \\
\hline & \multirow[b]{2}{*}{ Preliminary } & \multirow[b]{2}{*}{ Primary } & \multicolumn{3}{|c|}{ Enhanced primary (CEPT) } & \multicolumn{2}{|c|}{ Secondary plus } \\
\hline & & & Low dose & High dose & Primary & CEPT & $\begin{array}{l}\text { Nutrient } \\
\text { removal }\end{array}$ \\
\hline $\begin{array}{l}\text { Suspended } \\
\text { solids }\end{array}$ & $22 \pm 7$ & $55 \pm 14$ & $71 \pm 11$ & $92 \pm 6$ & $93 \pm 4$ & $93 \pm 5$ & 94 \\
\hline BOD Nutrients & $\mathrm{N} / \mathrm{A}$ & $20 \pm 11$ & $55 \pm 10$ & $78 \pm 11$ & $92 \pm 6$ & $95 \pm 4$ & 94 \\
\hline As mg/l TN & $\mathrm{N} / \mathrm{A}$ & $15 \pm 13$ & $37 \pm 11$ & $\mathrm{~N} / \mathrm{A}$ & $32 \pm 32$ & $\mathrm{~N} / \mathrm{A}$ & $84 \pm 4$ \\
\hline As mg/l TP & N/A & $38 \pm 19$ & $63 \pm 19$ & $93 \pm 3$ & $38 \pm 28$ & $87 \pm 4$ & $97 \pm 2$ \\
\hline $\begin{array}{l}\text { Relative cost } \\
\text { (US\$/MG) }\end{array}$ & 150 & 500 & 600 & 700 & 1.100 & 1.200 & 1.400 \\
\hline
\end{tabular}


Capital costs vary widely for different plants of the same type and in different countries for two main reasons. First, each process can be designed over a wide range of different criteria. The choice of design criteria affects the effluent quality and investment costs. For example, secondary treatment by activated sludge can be designed as high rate activated sludge with a detention time of 2-4 hours in the biological reactor, or as an extended aeration activated sludge with a detention of 1024 hours. The cost of an extended aeration reactor is much higher than that of a high rate reactor. Second, labor, material, and equipment costs, land costs as well as taxes and duties, vary in different countries. O\&M costs also vary due to different design criteria, and costs of labor, energy, chemicals and spare parts. Because of this uncertain variability, only typical values and not ranges are presented in Table 2 for O\&M costs.

The costs rise very rapidly as the level of treatment (and contaminant removal) increases. This is shown by the estimated annual costs to treat 100 $\mathrm{mgd}\left(4 \mathrm{~m}^{3} / \mathrm{s}\right)$ of raw wastewater in Figure 2 where the level of treatment is expressed by the percentage BOD removed. These costs include recovery of investment plus $O \& M$ costs.

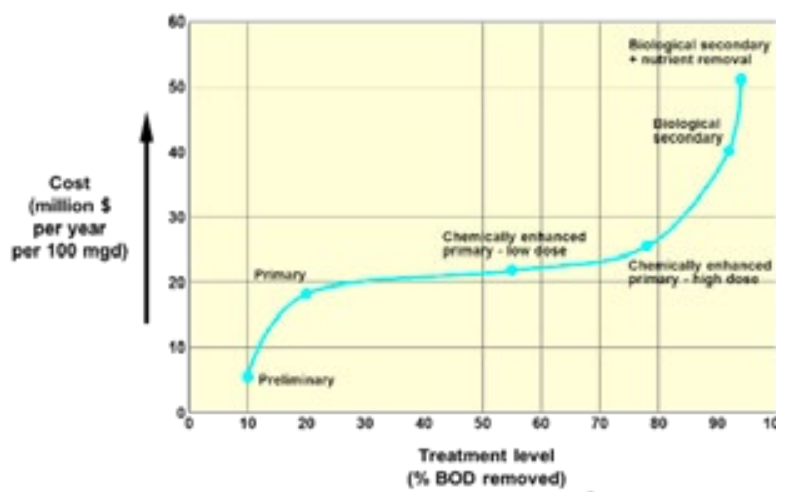

Figure 2: Relative costs of wastewater treatment

\section{CASE STUDY}

A recent case study that illustrates the relative costs and impacts of various treatment options is Cartagena, Colombia, Figure 3.
The scheme consists essentially of preliminary treatment by milliscreening without chlorination followed by discharge through a long outfall. The preliminary treatment plant was designed to remove floatable material such as oils and plastic bags, as well as sand and grit particles.

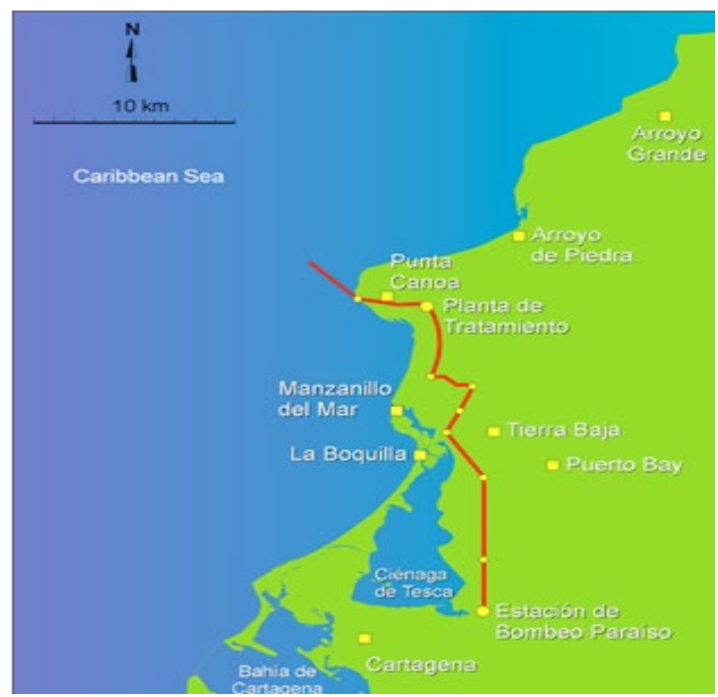

Figure 3: Cartagena, Colombia, outfall

The outfall extends approximately four $\mathrm{km}$ into the Caribbean Sea and terminates in a diffuser $520 \mathrm{~m}$ long in water depth of $20 \mathrm{~m}$.

The design flow rate is about $4 \mathrm{~m}^{3} / \mathrm{s}(\sim 100 \mathrm{mgd})$. Extensive measurements of currents and density stratification were made near the diffuser and used in mathematical modeling of the initial plume behavior and wastewater fate and transport (Roberts and Villegas, 2006).

It was found that dilutions should be very high, ranging from 84 to 860 with a median value of 230. Dilutions were greater than $100: 1$ for $85 \%$ of the time. Because of the weak stratification, the plume almost always surfaces, but when it does surface, the dilution is always greater than 85:1.

Far field modeling was performed to estimate the bacterial impacts, especially at the shoreline. Predictions of bacterial impacts are shown in Figure 4 expressed as areas where the WHO guidelines for Enterococci are exceeded. The outer contour cor- 
responds to WHO classification " $A$ ". This range is below the "no-observed-adverse-effect" (NOAEL) level for human health impacts.

It can be seen that bacterial impacts decrease rapidly with distance from the diffuser and bathing water standards will be met far from the shoreline and at the shoreline with a large margin of safety. This conclusion also applies to other bacterial criteria such as in the California Ocean Plan.

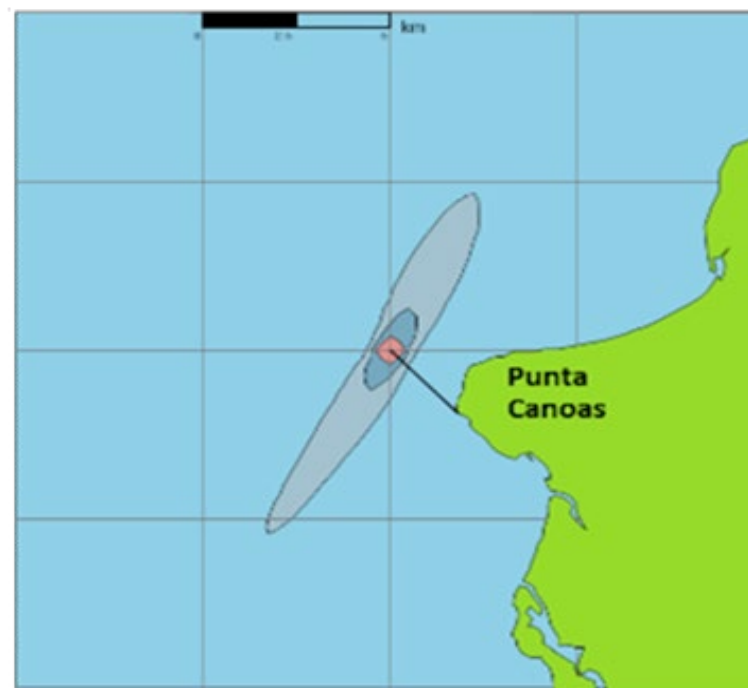

Figure 4: Bacterial simulation results compared to WHO (2003) guidelines

It was also found that all requirements for toxics of the California Ocean Plan would be met.

Since the outfall became operational and began discharging, a monitoring campaign has been under way and field observations have been regularly made such as at the stations shown in Figure 5. These include stations over the outfall and at shore. In addition, water quality monitoring at other key locations around the city have been performed.

The outfall is operating satisfactorily. Extensive water quality monitoring around the discharge area following international standards indicates that outside of the prescribed mixing zone there is no discernible impact on seawater quality.
Outside of the 500 meter mixing zone around the diffuser, BOD and suspended solid concentrations are equal to ambient seawater quality levels, and total coliform levels are less than 5 MPB/100 ml - an extremely low level considered suitable for human contact.

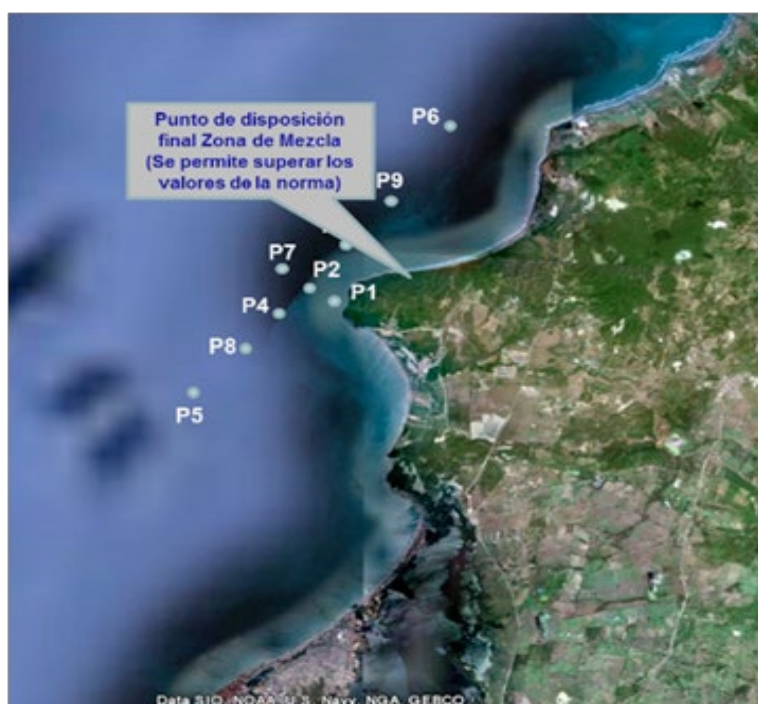

Figure 5: Field study locations for the Cartagena outfall.

The project has had many other benefits in cleaning up previously polluted areas. Cartagena's Caribbean beaches are now essentially free of contamination from sewage and the "red-flag" days of beach closures are history. Coliforms are a broad class of bacteria found in the environment, including the feces of man and other warm-blooded animals. The presence of coliform bacteria in water may indicate possible presence of harmful, disease-causing organisms. The Colombian standard for safe bathing is $1000 \mathrm{MPN} / 100 \mathrm{ml}$ and was frequently exceeded in the past. Total coliform concentrations on beaches and in the Cienega and Bay have declined dramatically after the wastewater treatment system has been commissioned.

The wastewater generated in the western part of the city, accounting for approximately $35 \%$ of the total pollution load, is now conveyed to the wastewater treatment plant and disposed through the 
submarine outfall. Pollution levels in the Bay, particularly alongside Cartagena in the "Inner Bay," are now significantly reduced.

The removal of wastewater discharges into the Lagoon, coupled with improved water circulation produced by the La Bocana project, has transformed the estuary. All key parameters, including coliforms, dissolved oxygen, biochemical oxygen demand, and suspended solids are now within regulatory standards and odor problems have been eliminated. The city is planning to transform the Lagoon and its surrounding area into a protected ecological park.

\section{RELATIVE COSTS}

Table 3 shows the relative costs of two outfall schemes: outfall plus preliminary treatment versus secondary treatment for the Cartagena outfall and also for the Taboada outfall in Lima, Peru.

Clearly, preliminary treatment is much less expensive. The savings can allow funds to be used for more pressing environmental and societal needs.

Table 3: Typical comparative costs of two outfall schemes with different treatment levels

\begin{tabular}{|c|c|c|c|c|c|}
\hline \multirow{3}{*}{ Location } & \multirow{3}{*}{$\begin{array}{c}\text { Treatment } \\
\text { Level }\end{array}$} & & \multicolumn{3}{|c|}{ Cost (million US\$) } \\
\hline & & \multicolumn{2}{|c|}{ Constrution } & \multirow{2}{*}{$\begin{array}{c}\text { O\&M } \\
\text { (per year) }\end{array}$} & \multirow{2}{*}{$\begin{array}{c}\text { Total Cost } \\
\text { Over } 25\end{array}$} \\
\hline & & Outfal & Plant & & \\
\hline \multirow{2}{*}{$\begin{array}{l}\text { Taboada, } \\
\text { Lima, Perú }\end{array}$} & Preliminary & 90 & 60 & 4 & 250 \\
\hline & Advanced & 50 & 400 & 18 & 900 \\
\hline \multirow{2}{*}{$\begin{array}{l}\text { Cartagena, } \\
\text { Colombia }\end{array}$} & Preliminary & 22 & 12 & 0.7 & 52 \\
\hline & Advanced & 22 & 150 & 13 & 97 \\
\hline
\end{tabular}

\section{CONCLUSIONS}

Wastewaters can be disposed of safely and economically into coastal waters with minimal economic impact. Water quality objectives and protection of human health can usually be met with an effective outfall, defined as one that has sufficient length and depth to ensure high initial dilution and to prevent sewage from reaching ar- eas of human usage, with preliminary treatment only. The combination of an effective outfall and preliminary treatment is particularly applicable to developing countries, where reliability and low cost are paramount. The science and technology of marine wastewater disposal is advancing rapidly on all fronts, from oceanographic instrumentation, mathematical modeling, and construction techniques that ensure reliable and economical systems.

Because domestic sewage is degradable, potential problems are, at most, local, and not regional or global. Mathematical modeling and monitoring of operating outfalls generally show that their effects are limited to a small area, typically a few hundred meters around the discharges.

Mixing zone regulations rather than effluent limitations are recommended, and arbitrary levels of treatment prior to discharge should be discouraged.

\section{REFERENCES}

NRC (1993). Managing Wastewater in Coastal Urban Areas, National Research Council, Committee on Wastewater Management for Coastal Urban Areas, National Academy Press, Washington, D.C.

Roberts, P. J. W., Salas, H. J., Reiff, F. M., Libhaber, M., Labbe, A., and Thomson, J. C. (2010). Marine Wastewater Outfalls and Treatment Systems, International Water Association, London.

Roberts, P.J.W., and Villegas, B.V. (2006). "Three-Dimensional Modeling of Bacterial Transport for the Cartagena Ocean Outfall." Prepared for Aguas de Cartagena, Cartagena, Colombia. 20 April 2006.

SWRCB (2015). "Water Quality Control Plan Ocean Waters of California.” State Water Resources Control Board, California Environmental Protection Agency, Sacramento, California, Adopted May 6, 2015, Effective January 28, 2016.

WHO (2003). "Guidelines for safe recreational water environments. Volume 12. Coastal and Fresh Waters." World Health Organization, 219, 2003. 